JIPPF, Vol. 1, Edisi 1, Halaman: 8-16

\title{
PENGEMBANGAN TES DIAGNOSTIK FOUR TIER TEST DILENGKAPI DENGAN SELF-DIAGNOSIS SHEET TENTANG ENERGI DI SMA
}

\author{
${ }^{1}$ Dendodi, ${ }^{2}$ Maria, H. T. ${ }^{3}$ Hamdani \\ 1,2,3Prodi Pendidikan Fisika, Universitas Tanjungpura, Kota Pontianak, Indonesia
}

*Email Korespondensi: aden.dendodi@gmail.com

\section{INFO ARTIKEL}

Diterima 00 Juni 2020

Dipublikasikan 00 Agustus 2020

\begin{abstract}
The purpose of this research is to produce a qualified diagnostic test that can be used to discover students' misconceptions about energy in high school's $10^{\text {th }}$ graders. This research uses Research and Development (R\&D) with the form of four tier test. The development of diagnostic test uses the adoption of Borg \& Gall development steps that has been simplified into seven steps. The inisial design consists of twelve item of test of multiple choices. The trial step of this diagnostic test was done to 35 students in the in the small scale trial, and 91 students in the large scale trial. According to the data analysis, it can be concluded that the developed diagnostic test is qualified of the use to discover students' misconceptions, because: 1) has higher validity than table validity, 2) has of reliabily of $0,783,3$ ) all items of the diagnostic can discover students' misconceptions, 4) has a diffuculty index $0,38,5$ ) the level of readability of the questions 0,63 . The qualified items that worth of use of this test are twelve items
\end{abstract}

Keywords: Energy, Four Tier Diagnostic Test, Self-diagnosis Sheet

\section{Pendahuluan}

Tujuan suatu pembelajaran menurut Permendikbud No.20 Tahun 2016 adalah unit kompetensi terkecil yang harus dikuasi peserta didik dalam rangka mencapai standar kompetensi lulusan. Tujuan pembelajaran dibuat menjadi acuan untuk menentukan jenis materi pembelajaran, strategi pembelajaran, metode pembelajaran dan media pembelajaran. Menurut Tatlah (2017) Keberhasilan dari proses pembelajaran dapat dilihat dari tercapainya tujuan pembelajaran jangka pendek dan jangka panjang tujuan proses pembelajaran. Pembelajaran efektif merupakan pembelajaran yang dapat menuntun peserta didik mencapai kemajuan maksimal, sesuai dengan kemampuan yang dimilikinya. Seorang guru yang baik tentu selalu berusaha menciptakan pembelajaran yang selalu efektif. Zaleha (2017) menyatakan bahwa pada kenyataannya pembelajaran tidak selalu efektif, tidak semua peserta didik dapat mencapai kemajuan secara maksimal dalam proses pembelajaran, ada banyak faktor yang mempengaruhi proses belajar peserta didik salah satunya adalah kesulitan belajar.

Penelitian yang dilakukan oleh Fauzan (2010) mendeskripsikan kesulitan-kesulitan yang dialami peserta didik terhadap materi ajar sesuai dengan indikator yang telah dirumuskan. Penelitian yang dilakukan oleh Waskito \& Kumaidi (2010) memberikan informasi tentang skor dan nilai tiap peserta didik dan memberikan saran apa saja yang harus dipelajari untuk mengatasi kesulitan tiap butir soal, serta memberikan informasi prestasi setiap peserta didik dibandingkan dengan teman sekelasnya. Berdasarkan hal tersebut banyak peneliti sudah menggunakan berbagai instrumentasi untuk mengetahui kesulitan belajar peserta didik. Salah satu instrumentasi yang dipakai seperti alat ungkap masalah (AUM), daftar cek masalah (DCM), sosiometri, angket dan observasi. Saat ini sudah banyak instrumen yang dibuat untuk mendeteksi dan mengklasifikasi masalah peserta didik, baik dalam kesulitan belajar maupun peserta didik yang mengalami miskonsepsi. Pada penelitian ini instrumen yang digunakan berupa tes diagnostik.

Menurut Depdiknas (2007) tes diagnostik adalah tes yang digunakan untuk mengetahui kelemahan peserta didik dalam memahami suatu materi. Tes ini dapat berupa sejumlah pertanyaan atau permintaan untuk melakukan sesuatu. Hasil dari tes diagnostik dapat digunakan sebagai dasar untuk memberikan perlakuan yang tepat dan sesuai dengan kelemahan yang dimiliki peserta didik. Kurikulum 2013 juga mengamanatkan penilaian hasil belajar 
peserta didik harus dilaksanakan secara autentik. Penilaian autentik menuntut guru agar dapat mengamati perkembangan peserta didik pada semua aspek perkembangan termasuk juga perkembangan afektif dan psikomotor. Oleh karena itu, seorang guru wajib mengembangkan tes untuk menggali penilaian autentik berupa tes diagnostik. Pengembangan tes diagnostik pada penelitian pengembangan ini menggunakan tes diagnostik four tier test.

Beberapa bentuk tes diagnostik salah satunya adalah tes diagnostik pilihan ganda yang diantaranya : tes diagnostik pilihan ganda one-tier (satu tingkat), two-tier (dua tingkat), three-tier (tiga tingkat) dan four-tier (empat tingkat). Tes diagnostik pilihan ganda empat tingkat merupakan pengembangan dari tes diagnostik pilihan ganda tiga tingkat, yaitu dengan menambahkan tingkat keyakinan pada masing-masing jawaban dan alasan (Caloen \& Subramaniam, 2010). Penambahan tingkat keyakinan pada masing-masing jawaban dan alasan dapat mengukur perbedaan tingkat pengetahuan peserta didik sehingga akan membantu dalam mendeteksi tingkat miskonsepsi peserta didik. Pengembangan tes diagnostik pada penelitian pengembangan ini menggunakan tes diagnostik four tier test. Tier pertama dari setiap item dalam tes merupakan pernyataan proporsional dan bagian dari peta konsep yang dibuat dalam bentuk pilihan ganda. Tier kedua berisi tentang tingkat keyakinan peserta didik dalam menjawab tier pertama. Tier ketiga berisi alasan yang harus dipilih oleh peserta didik yang menjelaskan jawaban pada tier pertama dan dalam bentuk pilihan ganda. Himpunan alasan terdiri dari jawaban ilmiah dan kesalahan pemahaman konsep yang mungkin dimiliki oleh peserta didik. Tier keempat atau yang terakhir berisi tingkat keyakinan peserta didik dalam menjawab tier ketiga.

Menurut Rusilowati (2015) tes diagnostik four tier test memiliki kelebihan dibanding tes diagnostik pilihan ganda yang telah ada sebelumnya. Melalui tes diagnostik pilihan ganda empat tingkat guru dapat: (1) membedakan tingkat keyakinan jawaban dan tingkat keyakinan alasan yang dipilih peserta didik sehingga dapat menggali lebih dalam tentang kekuatan pemahaman peserta didik, (2) mendiagnosis miskonsepsi yang dialami peserta didik lebih dalam, (3) menentukan bagian-bagian materi yang memerlukan penekanan lebih, dan (4) merencanakan pembelajaran yang lebih baik untuk membantu mengurangi miskonsepsi peserta didik. Tes diagnostik pada materi energi yang dikembangkan oleh mahasiswa FKIP Untan masih berbentuk one tier test. Tes diagnostik bentuk one tier test masih memiliki kekurangan, yaitu memungkinkan peserta didik untuk menjawab soal dengan benar karena kebetulan atau keberuntungan. Sedangkan penelitan yang telah dilakukan masih banyak menemukan peserta didik yang mengalami miskonsepi pada materi energi. Oleh karena itu, tes yang digunakan untuk menggali miskonsepsi dirancang dengan baik agar konsepsi peserta didik dapat diketahui dengan jelas dari tes yang dibuat. Dari kelemahan tersebut, dikembangkan tes diagnostik dengan bentuk four tier test.

Dolan (2010) menyatakan bahwa sangat sulit untuk membedakan peserta didik yang tidak tahu konsep dan peserta didik yang mengalami miskonsepsi. Tes diagnostik pilihan ganda empat tingkat dirancang untuk menentukan seberapa kuat peserta didik menguasai konsep melalui tingkat keyakinan dalam menjawab pertanyaan. Selain itu pada penelitian ini peserta didik juga diminta melakukan diagnosa kemampuan diri dalam menyelesaikan soal tersebut. Proses diagnosa diri ini sering disebut dengan self-diagnosis. Self-diagnosis merupakan proses untuk mendiagnosa atau mengidentifikasi kondisi dalam diri sendiri, sedangkan self-diagnosis sheet merupakan lembar diagnosis diri peserta didik dalam mengetahui kesalahan peserta didik dalam menyelesaikan soal. Dengan menganalisis kemampuan diri dari peserta didik, peneliti dapat mengetahui apa saja yang menjadi dasar sulitnya belajar bagi peserta didik. Kesulitan belajar peserta didik dalam menyelesaikan soal perlu di diagnosis kembali agar sumber masalahnya dapat ditindak lanjuti untuk mengatasi masalah tersebut. Salah satu tujuan diadakannya self-diagnosis ini adalah untuk mengetahui sejauh mana peserta didik mampu menyelesaikan soal dan apa-apa saja kesulitan yang dialami peserta didik saat menyelesaikan soal tersebut. Untuk penilaian diagnostik ini berupa tes diagnostik yang diberikan kepada peserta didik.

Tes diagnostik berfungsi untuk mengetahui kekuatan dan kelemahan dalam pembelajaran sehingga pembelajaran dapat diperbaiki dan tujuan pembelajaran tercapai. Penilaian diagnostik dapat mengungkapkan ketidakpahaman peserta didik dalam memahami konsep-konsep melalui sub-sub konsep yang dijawab tidak benar 
oleh peserta didik melalui konsep tiap butir soal. Selain itu, untuk memperkuat hasil analisis tes diagnostik pada peserta didik perlu dlakukannya wawancara terhadap peserta didik yang mengalami kesulitan belajar (Suwarto, 2013). Sion \& Jingan (dalam Suwarto, 2013) menyatakan tes diagnostik sebagai tes yang memberikan informasi kepada guru tentang kemampuan awal dan miskonsepsi peserta didiknya sebelum memulai aktivitas. Tes diagnostik juga dilakukan agar kelemahan peserta didik tersebut dapat diminimalkan sehingga kemampuannya peserta didik pun dapat di tingkatkan. Dengan penilaian diagnostik tersebut dapat diketahui hal-hal yang perlu untuk diperbaiki dan ditingkatkan serta hal-hal yang perlu dipertahankan dalam melaksanakan pembelajaran. Berdasarkan uraian di atas, dilakukannya penelitian mengenai pengembangan tes diagnostik yang bertujuan untuk mengetahui miskonsepsi peserta didik dengan judul "Pengembangan Tes Diagnostik Four Tier Test Dilengkapi Dengan Self-diagnosis Sheet Tentang Energi di SMA".

\section{Metode Penelitian}

Jenis penelitian ini merupakan penelitian dan pengembangan atau biasa disebut Research and Development (R\&D). Sugiono (2015) menyatakan bahwa R\&D adalah metode penelitian yang digunakan untuk menghasilkan produk tertentu, dan menguji keefektifan produk tersebut. Untuk dapat menghasilkan produk tertentu digunakan penelitian yang bersifat analisis kebutuhan dan untuk menguji keefektifan produk tersebut. Pengembangan tes diagnostik four tier test yang dilakukan mengadopsi pada langkah-langkah pengembangan dari Borg \& Gall (1983) yang telah disederhanakan menjadi 7 langkah yang terdiri dari: (1) pengumpulan data awal, (2) perencanaan, (3) desain produk, (4) uji coba skala kecil, (5) revisi produk awal, (6) uji coba skala besar, dan (7) revisi produk akhir hingga menghasilkan instrumen tes diagnostik four tier test yang layak digunakan untuk mengungkap miskonsepsi peserta didik pada materi energi.

Prosedur penelitian dan pengembangan tes diagnostik four tier test yag dilengkapi dengan self-diagnosis sheet ialah sebagai berikut: Tahap pertama pengumpulan data awal. Pengumpulan data awal dilakukan dengan studi literatur ke salah satu Sekolah Menengah Atas (SMA) Negeri yang ada di Kota Pontianak berkaitan dengan permasalahan yang dikaji yaitu tentang tes diagnostik. Hasil studi literatur mengenai tes diagnostik yaitu guru belum pernah memberikan tes diagnostik untuk mengetahui miskonsepsi peserta didik. Kesimpulan dari beberapa permasalahan yang diangkat pada studi literatur maka perlu dibuat pengembangan tes diagnostik yang layak digunakan. Tahap kedua ialah perencanaan. Pada tahap ini materi yang dikembangkan menjadi instrumen tes diagnostik adalah materi energi. Instrumen tes diagnostik yang dikembangkan berdasarkan miskonsepsi pada penelitian sebelumnya. Rancangan instrumen dalam penelitian ini yaitu tes diagnostik four tier test, yang terdiri dari soal, jawaban dengan tiga pilihan, keyakinan dalam menjawab soal, alasan memilih jawaban dan keyakinan dalam menjawab alasan.

Tahap ketiga melakukan desain produk. Pada tahap ini, dibagi menjadi tiga tahap yaitu menyusun spesifikasi tes, menulis soal tes dan menelaah tes. Langkah awal dalam menyusun spesifikasi tes terdiri dari tiga tahap yaitu menentukan tujuan tes, menyusun kisi-kisi dan menentukan bentuk tes. Tujuan tes diagnostik yaitu menghasilkan tes yang layak digunakan untuk mengungkap miskonsepsi peserta didik pada materi energi kelas $\mathrm{X}$ sedangkan bentuk tes yang dipilih dalam pembuatan tes diagnostik adalah tes pilihan ganda. Tahap keempat melakukan uji coba produk skala kecil. Uji coba produk skala kecil dilakukan di kelas XI MIA 2 SMA Negeri 2 Pontianak tahun ajaran 2018/2019. Uji skala kecil diikuti oleh 35 orang peserta didik di kelas tersebut. Tahap kelima melakukan revisi produk awal. pada tahap ini soal tes diagnostik yang telah diuji cobakan kemudian direvisi dan dirakit kembali sesuai dengan data karakteristik tes yang diinginkan. Data yang dianalisis meliputi reliabilitas, validitas dan tingkat kesukaran.

Tahap keenam melakukan uji coba skala besar. Uji coba skala besar dilakukan di kelas XI MIA 1 SMA Negeri 2 Pontianak, kelas X MIA 2 SMA Negeri 7 Pontianak dan kelas X MIA 2 SMA Negeri 1 Sambas dengan jumlah peserta didik 91 orang. Tes yang diuji cobakan sebanyak 12 soal dengan waktu 90 menit. Tahap ketujuh melakukan revisi produk akhir. Langkah terakhir dalam pengembangan tes yaitu revisi dan analisis soal tes diagnostik dari uji coba 
skala besar. Pada tahap ini, dicari nilai validitas soal, reliabilitas soal dan tingkat kesukaran. Tujuan dari revisi produk akhir yaitu didapatkan produk pengembangan tes yang sesuai dengan karakteristik tes yang baik. Teknik pengumpulan data pada penelitian ini yaitu melalui tes dan wawancara. Tes terbagi menjadi dua tahap yaitu tes diagnostik skala kecil dan tes diagnostik skala besar, tes diagnostik skala kecil dipilih berdasarkan nilai Ujian Nasioanal (UN) dengan kategori sedang dengan jumlah sampel penelitian yang terbatas, sedangkan tes diagnostik skala besar dipilih berdasarkan nilai UN sedang atau tinggi dengan jumlah sampel yang tidak terbatas. Teknik pengumpulan data yang kedua yaitu wawancara, teknik ini dilakukan agar permasalahan mengenai tes diagnostik dan kesulitan belajar peserta didik bisa diketahui. Kesimpulan dari hasil wawancara akan menjadi bahan pertimbangan dan bahan kajian dalam pembuatan rancangan awal tes diagnostik dan dalam menentukan materi yang akan dibuat.

\section{Hasil dan Pembahasan}

\subsection{Hasil}

Tes diagnostik yang dikembangkan tidak untuk menilai hasil belajar peserta didik. Tes yang dikembangkan hanya bertujuan untuk mengungkapkan miskonsepsi peserta didik dan kesulitan belajar peserta didik. Tiga bentuk miskonsepsi peserta didik berdasarkan studi literatur yang terdiri dari semakin rendah posisi benda maka energi kinetiknya semakin kecil pada benda yang bergerak ke atas, energi mekanik suatu partikel selalu berkurang jika energi potensial gravitasinya berkurang dan energi kinetik akhir partikel yang dipindahkan tergantung pada bentuk lintasan dapat dibuktikan dengan adanya peserta didik yang mengalami miskonsepsi pada saat tes diagnostik dikerjakan. Butir soal yang layak adalah butir soal yang memenuhi seluruh kriteria tes diagnostik yang baik, berikut hasil rekapitulasi butir soal tes diagnostik yang dapat dilihat pada Tabel 1.

Tabel 1. Rekapitulasi Kelayakan Tes

\begin{tabular}{ccccccc}
\hline No & Validitas & Reliabilitas & $\begin{array}{c}\text { Dapat Mendeteksi } \\
\text { Miskonsepsi }\end{array}$ & $\begin{array}{c}\text { Tingkat } \\
\text { Kesukaran }\end{array}$ & $\begin{array}{c}\text { Tingkat } \\
\text { Keterbacaan }\end{array}$ & Kategori \\
\hline 1. & 0,660 & 0,753 & 1 & 0,67 & 6,36 & Layak \\
\hline 2. & 0,637 & 0,757 & 1 & 0,41 & 7,19 & Layak \\
\hline 3. & 0,210 & 0,797 & 1 & 0,16 & 7,24 & Layak \\
\hline 4. & 0,496 & 0,775 & 1 & 0,59 & 6,41 & Layak \\
\hline 5. & 0,729 & 0,744 & 1 & 0,29 & 6,41 & Layak \\
\hline 6. & 0,483 & 0,774 & 1 & 0,24 & 6,07 & Layak \\
\hline 7. & 0,647 & 0,755 & 1 & 0,27 & 6,70 & Layak \\
\hline 8. & 0,368 & 0,782 & 1 & 0,15 & 6,36 & Layak \\
\hline 9. & 0,573 & 0,765 & 1 & 0,30 & 7,40 & Layak \\
\hline 10. & 0,460 & 0,777 & 1 & 0,21 & 6,27 & Layak \\
\hline 11. & 0,703 & 0,748 & 1 & 0,23 & 6,41 & Layak \\
\hline 12. & 0,473 & 0,775 & 1 & 0,53 & 6,79 & Layak \\
\hline
\end{tabular}

Karakteristik kelayakan tes diagnostik ini yaitu: memiliki validitas isi lebih tinggi dari validitas tabel yaitu 0,207, memiliki reliabilitas minimal 0,6, dapat mendeteksi miskonsepsi peserta didik ( $1=\mathrm{Ya}, 0=$ Tidak), memiliki tingkat kesukaran sedang atau tinggi $(T K . \leq 0,69)$ dan tingkat keterbacaan $\geq 6$. Interpretasi hasil tes diagnostik four tier test merupakan penafsiran tingkat jawaban peserta didik yang mana dari penafsiran tersebut didapat hasil keputusan four tier test. Menurut Amin, et all (2016) tingkat keputusan tes diagnostik four tier test ada 16 kategori keputusan yang semuanya memiliki kriteria kategori masing-masing. Adapun hasil dari interpretasi tes diagnostik four tier test yang diujikan diringkas pada Tabel 2.

Tabel 2. Interpretasi Hasil Tes Diagnostik Four Tier Test 


\begin{tabular}{ccccc}
\hline No Soal & Miskonsepsi & $\begin{array}{c}\text { Tidak Paham } \\
\text { Konsep }\end{array}$ & $\begin{array}{c}\text { Paham } \\
\text { Konsep }\end{array}$ & Paham Sebagian \\
\hline 1. & 19 orang & 2 orang & 62 orang & 8 orang \\
\hline 2. & 41 orang & 10 orang & 39 orang & 1 orang \\
\hline 3. & 64 orang & 10 orang & 14 orang & 3 orang \\
\hline 4. & 21 orang & 4 orang & 55 orang & 11 orang \\
\hline 5. & 38 orang & 20 orang & 24 orang & 9 orang \\
\hline 6. & 51 orang & 12 orang & 21 orang & 7 orang \\
\hline 7. & 40 orang & 16 orang & 21 orang & 14 orang \\
\hline 8. & 66 orang & 7 orang & 15 orang & 3 orang \\
\hline 10. & 42 orang & 16 orang & 29 orang & 4 orang \\
\hline 11. & 54 orang & 15 orang & 18 orang & 4 orang \\
\hline 12. & 44 orang & 20 orang & 20 orang & 7 orang \\
\hline Jumlah total & 16 orang & 6 orang & 45 orang & 24 orang \\
\hline$\%$ & 496 & 138 & 363 & 95 \\
\hline
\end{tabular}

Self-diagnosis sheet yaitu lembar identifikasi diri peserta didik untuk mengetahui kesalahan peserta didik dalam menyelesaikan soal. Self-diagnosis sheet di analisis untuk mengetahui kesulitan peserta didik dalam menjawab soal dengan memberikan evaluasi alasan peserta didik dalam menjawab pilihan dalam tes diagnostik. Alasan peserta didik dalam memberikan pernyataan dapat dilihat pada Tabel 3.

Tabel 3. Alasan Peserta Didik

\begin{tabular}{|c|c|c|}
\hline Bentuk Miskosepsi & & Alasan Peserta Didik \\
\hline \multirow[t]{3}{*}{$\begin{array}{l}\text { Semakin rendah posisi benda } \\
\text { maka energi kinetiknya } \\
\text { semakin kecil pada benda } \\
\text { yang bergerak ke atas }\end{array}$} & b) & $\begin{array}{l}\text { Peserta didik menganggap semakin tinggi posisi suatu benda dari } \\
\text { permukaan tanah maka energi kinetik benda tersebut semakin besar } \\
\text { artinya ketinggian berbanding lurus dengan energi kinetik. } \\
\text { Peserta didik menganggap energi kinetik yang paling besar posisinya } \\
\text { selalu berada di tengah-tengah karena posisi di tengah-tengah } \\
\text { merupakan posisi yang paling memungkin lebih besar energi kinetiknya } \\
\text { sebab saat benda dipuncak ketinggian maksimum dan tepat akan } \\
\text { dilontarkan benda tidak bergerak. }\end{array}$ \\
\hline & c) & $\begin{array}{l}\text { Peserta didik menganggap energi kinetik itu sama dengan energi } \\
\text { potensial sehingga banyak peserta didik yang kurang memahami } \\
\text { materi energi kinetik. }\end{array}$ \\
\hline & d) & $\begin{array}{l}\text { Peserta didik menganggap energi kinetik besarnya selalu sama pada } \\
\text { saat benda bergerak secara vertikal karena energi kinetik akan } \\
\text { berkurang atau bertambah jika benda bergerak secara horizontal saja. }\end{array}$ \\
\hline \multirow{3}{*}{$\begin{array}{l}\text { Energi mekanik suatu partikel } \\
\text { selalu berkurang jika energi } \\
\text { potensial } \quad \text { gravitasinya } \\
\text { berkurang }\end{array}$} & a) & $\begin{array}{l}\text { Peserta didik menganggap semakin tinggi posisi suatu benda dari } \\
\text { permukaan tanah maka energi mekanik benda tersebut semakin besar } \\
\text { artinya ketinggian berbanding lurus dengan energi mekanik. }\end{array}$ \\
\hline & b) & $\begin{array}{l}\text { Peserta didik menganggap semakin tinggi posisi suatu benda dari } \\
\text { permukaan tanah maka energi mekanik benda tersebut semakin kecil } \\
\text { artinya ketinggian berbanding terbalik dengan energi mekanik. }\end{array}$ \\
\hline & c) & $\begin{array}{l}\text { Peserta didik menganggap energi mekanik pada suatu benda tidak } \\
\text { konstan melainkan tergantung pada energi kinetik atau energi potensial }\end{array}$ \\
\hline
\end{tabular}




\begin{tabular}{|c|c|c|}
\hline Bentuk Miskosepsi & & Alasan Peserta Didik \\
\hline & & yang bekerja. \\
\hline \multirow[t]{5}{*}{$\begin{array}{l}\text { Energi kinetik akhir partikel } \\
\text { yang dipindahkan tergantung } \\
\text { pada bentuk lintasan }\end{array}$} & a) & $\begin{array}{l}\text { Peserta didik menganggap lintasan yang lebih panjang akan } \\
\text { mempunyai energi kinetik yang besar karena waktu yang dibutuhkan } \\
\text { untuk sampai di garis akhir lebih besar. }\end{array}$ \\
\hline & b) & $\begin{array}{l}\text { Peserta didik menganggap lintasan yang lebih pendek akan } \\
\text { mempunyai energi kinetik yang besar karena waktu yang dibutuhkan } \\
\text { untuk sampai di garis akhir lebih kecil. }\end{array}$ \\
\hline & c) & $\begin{array}{l}\text { Peserta didik menganggap lintasan yang curam akan mempunyai } \\
\text { energi kinetik yang besar karena tidak ada hambatan yang } \\
\text { menghalangi benda tersebut sampai garis akhir. }\end{array}$ \\
\hline & d) & $\begin{array}{l}\text { Peserta didik menganggap lintasan yang mempunyai sudut besar akan } \\
\text { mempunyai energi kinetik yang besar. }\end{array}$ \\
\hline & e) & $\begin{array}{l}\text { Peserta didik menganggap lintasan yang mempunyai sudut kecil akan } \\
\text { mempunyai energi kinetik besar. }\end{array}$ \\
\hline
\end{tabular}

\subsection{Pembahasan}

Tes diagnostik adalah tes yang dirancang khusus untuk mengetahui kelemahan-kelemahan konsep atau miskonsepsi yang berada dalam diri peserta didik (Suwarto, 2013). Tujuan dari tes diagnostik yaitu untuk mengetahui kesalahan konsep peserta didik pada materi energi untuk SMA. Penelitian pengembangan tes diagnostik didasarkan pada penelitian dan pengembangan (research and develepment) menurut Mardapi (2012). Penelitian ini melibatkan peserta didik kelas XI MIA 1 di SMA Negeri 2 Pontianak, kelas X MIA 2 di SMA Negeri 7 Pontianak dan kelas X MIA 2 di SMA Negeri 1 Sambas. Tes diagnostik yang dikembangkan pada penelitian ini tes diagnostik four tier test yaitu tes iagnostik pilihan ganda yang dibuat empat tingkat. Intstrumen tes yang berhasil dibuat sebanyak 12 soal dengan mengembangkan 3 bentuk miskonsepsi yang dialami peserta didik SMA yang didapat pada penelitian sebelumnya.

Soal tes diagnostik sebelum diujikan kepada peserta didik terlebih dahulu dilakukan penelaahan instumen dengan dibantu oleh 2 orang dosen pembimbing dan divalidasi oleh 5 orang validator yang terdiri dari 2 orang dosen pendidikan fisika dan 3 orang guru fisika. Pada tahap validasi validator memperbaiki soal dengan memberikan saran dan komentar terhadap soal yang telah peneliti buat. Kemudian penilaian yang diberikan validator berkisar dari rentang 1 hingga 5. Tes diagostik yang dikembangkan sesuai dengan 5 karakteristik menurut Sudijono (2011). Adapun 5 karateristik tersebut sebagai berikut.

Memiliki validitas lebih tinggi dari validitas tabel, validitas adalah sejauh mana ketepatan dan kecermatan suatu alat ukur tes dalam melakukan fungsi ukurnya (Azwar, 2009). Validitas penelitian ini ada 2 validitas yang dilakukan yaitu validitas isi dan validitas butir tes. Validitas isi yang dilakukan oleh beberapa orang validator dihitung menggunakan microsoft excel yang hasil keseluruhan adalah sebesar 0,73 yang termasuk dalam kategori tinggi. Validitas butir tes dianalisis menggunakan SPSS, untuk soal skala besar dikatakan valid jika memiliki product moment $\geq 0,207$. Pada uji skala besar soal dinyatakan semuanya valid, hal ini terjadi karena setelah uji skala kecil soal-soal yang tidak valid diperbaiki urutan pilihan dan gambar-gambar yang kurang jelas. Memiliki reliabilitas $\geq 0,60$, reliabilitas adalah sejauh mana hasil suatu pengukuran dapat dipercaya (Azwar, 2009). Hasil reliabilitas total secara keseluruhan pada uji skala besar adalah 0,783 dan termasuk dalam kategori reliabilitas kuat. Hasil ini menunjukkan reliabilitas yang tinggi maka dengan kata lain, tes diagnostik yang dikembangkan dapat dipercaya saat uji skala besar.

Dapat mendeteksi miskonsepsi peserta didik, soal tes diagnostik yang dibuat dalam penelitian ini sesuai dengan tujuan tes tersebut yaitu dapat mengungkapkan kesalahan konsep (miskonsepsi) peserta didik pada materi energi. Soal tes diagnostik yang dikembangkan dapat mengungkap miskonsepsi peserta didik dapat 
dilihat dari jawaban peserta didik yang bervariasi dalam menjawab soal tes diagnostik. Selain itu, jawaban peserta didik dalam tes diagnostik ini juga tidak hanya dinominasi hanya satu pilihan jawaban. Tingkat kesukaran sedang atau tinggi dengan nilai $\leq 0,69$, tingkat kesukaran soal menyatakan sukar atau tidaknya soal dijawab oleh peserta didik dalam uji tes yang sebenarnya merupakan nilai rata-rata dari kelompok peserta didik. Tes diagnostik dibuat bukan untuk membedakan peserta didik berdasarkan kemampuannya, soal yang baik harus memiliki tingkat kesukaran yang sedang atau tinggi. Hasil uji coba produk skala besar menunjukan tingkat kesukaran tiap butir soal semuanya memiliki tingkat kesukaran sedang dan tinggi. Item dibuat dengan bahasa yang sederhana dan jelas yang dinyatakan dengan tingkat keterbacaan $\geq 6$, rata-rata tingkat keterbacaan soal tes diagnostik adalah 6,63 maka tes sesuai diberikan kepada peserta didik jenjang SMA/MA. Apabila soal yang diberikan memiliki tingkat keterbacaan yang terlalu kecil dari 6 , maka peserta didik akan mengalami kesulitan dalam membaca, memahami dan mengaplikasikan soal tersebut. Berikut gambar soal tes diagnostik yang memiliki tingkat keterbacaan rendah dan tingkat keterbacaan tinggi seperti pada Gambar 1.

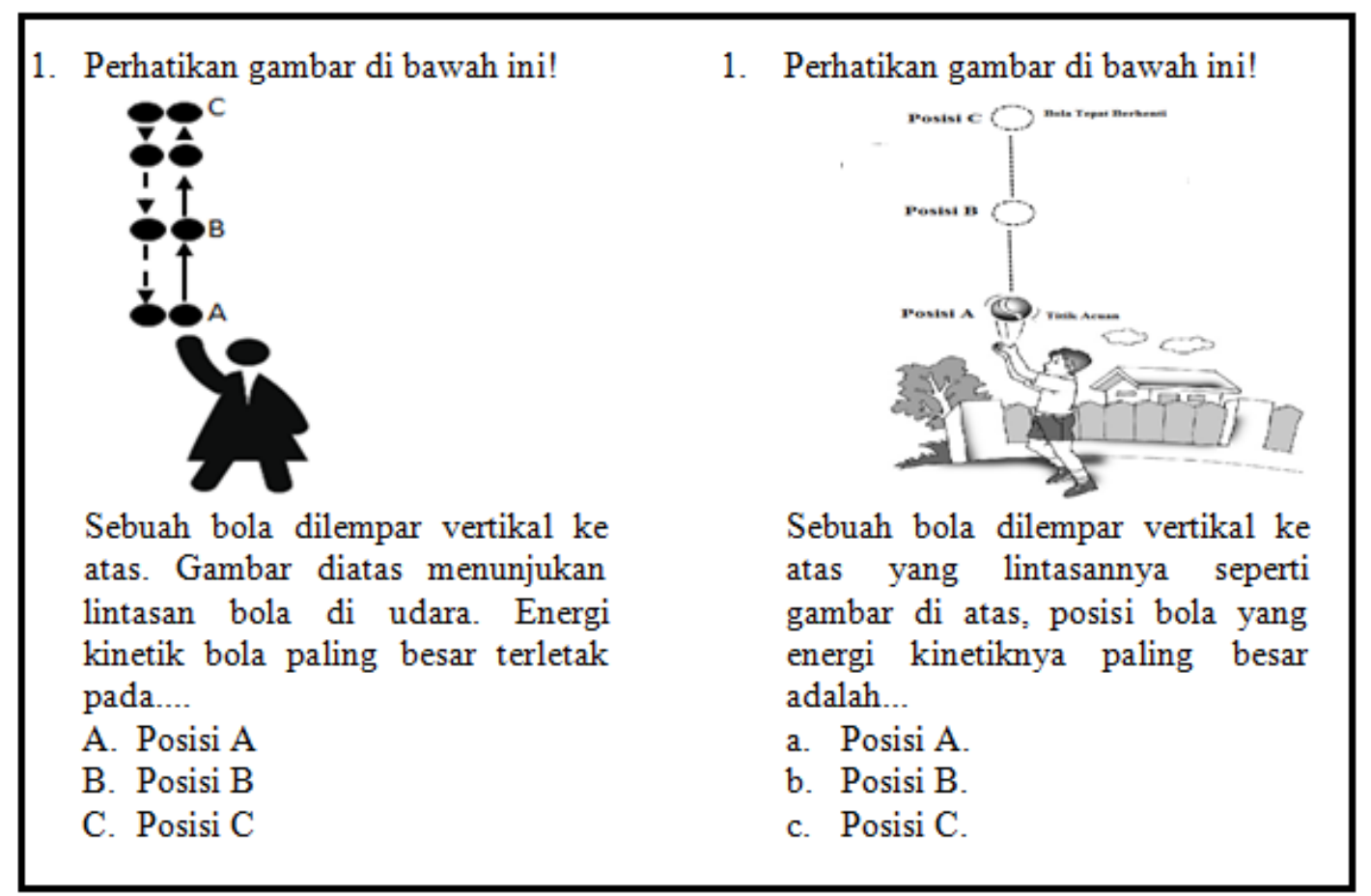

Gambar 1. Tingkat Keterbacaan Rendah dan Tingkat Keterbacaan Tinggi

Item tes diagnostik dinyatakan dapat dipakai ditinjau dari 5 kelayakan karakteristik butir tes. Berdasarkan hasil analisis data, 12 soal tes diagnostik yang dikembangkan seluruhnya memiliki karakteristik tes yang sesuai dengan persyaratan tes diagnostik yang baik. Soal tes diagnostik ini juga dapat digunakan untuk mengungkapkan miskonsepsi peserta didik maka dari itu 12 soal yang dikembangkan layak digunakan. Berdasarkan hasil penelitian yang dilakukan pada tiga sekolah di Kota Pontianak dan di Kabupaten Sambas, diperoleh peserta didik yang mengalami miskonsepsi sebesar 45,4 \%, peserta didik yang tidak paham konsep sebesar 12,6\%, peserta didik yang paham konsep sebesar 33,2 \% dan peserta didik yang paham sebagian 8,7 $\%$. Penafsiran keputusan tingkat jawaban peserta didik ini berdasarkan hasil keputusan four tier test menurut Amin, et all (2016).

\section{KESIMPULAN}

Berdasarkan pembahasan yang telah dijabarkan, dapat disimpulkan secara umum bahwa tes diagnostik four tier test yang dilengkapi dengan self-diagnosis sheet pada penelitian ini dapat digunakan untuk menggali miskonsepsi dan kesulitan belajar peserta didik pada materi energi. Adapun simpulan secara khusus berdasarkan karakteristik tes diagnostik yang baik adalah sebagai berikut: Memiliki validitas yang lebih tinggi daripada validitas tabel, 
memiliki reliabilitas sebesar 0,783 , setiap butir soal tes diagnostik dapat mengungkap miskonsepsi peserta didik, memiliki indeks kesukaran 0,38, tingkat keterbacaan sebesar 0,63 dan diperjelas dengan gambar disetiap soal.

Adapun analisis jawaban yang dilakukan pada penelitian ini adalah sebagai berikut: memiliki tingkat validitas isi tinggi (antara 0,61 sampai dengan 1), memiliki tingkat validitas soal berdasarkan tabel $r$ product momen sebesar: validitas butir 35 peserta didik minimal: 0,334 dan validitas butir 91 peserta didik minimal: 0,207. Memiliki tingkat reliabilitas $r_{11}$ yang tinggi (memiliki $r_{11} \geq 0,70$ ), memiliki tingkat kesukaran yang bervariasi (sedang dan sukar). tingkat keterbacaan lebih besar atau sama dengan 6. Jumlah butir soal tes diagnostik yang memenuhi 5 karakteristik tes yang baik menurut Sudijono (2011) adalah berjumlah 12 soal atau semua soal memenuhi karakteristik tersebut. Soal tersebut terdiri dari 3 bentuk miskonsepsi dan 3 indikator. Indikator 1 berjumlah 3 soal tes diagnostik, indikator 2 berjumlah 4 soal tes diagnostik dan indikator 3 berjumlah 5 soal tes diagnostik.

\section{Referensi}

Amin, N. Wiendartun. Samsudin, A, (2016). 'Analisis Instrumen Tes Diagnostik Dynamic-Fluid Conceptual Change Inventory (DFCCI) Bentuk Four-Tier Test pada Beberapa SMA di Bandung Raya', Simposium Nasional Inovasi dan Pembelajaran Sains (SNIPS), pp 570-574.

Azwar, S. (2009). Reliabilitas dan Validitas. Yogyakarta: Pustaka Pelajar

Borg, W.R, \& Gall, M.D. (1983). Education Research An Introduction. New York : Longman.

Caloen, I. S. \& Subramaniam, R. (2010). "Do Students Know What They Know and What They Don't Know? Using a Four-Tier Test to Assess the Nature Of Students'. Alternatif Conceptions". Res Sci Euc, 40 : 313-337.

Departemen Pendidikan Nasional. (2007). Tes Diagnostik. Jakarta: Direktorat Pembinaan Sekolah Menengah Pertama.

Dolan, E. (2010). "Recent Researh in Science Teaching and Learning". CBE-Life Science Education, 9: 76-77.

Fauzan. (2010). Pengembangan Tes Diagnostik Kesulitan Belajar Fisika di SMA. Disertasi. Yogyakarta: PPs UNY.

Republik Indonesia.2003. Undang-undang Nomor 20 Tahun 2003 Tentang Sistem Pendidikan Nasional. Sekretariat Negara.Jakarta.

Rusillowati, Ani. (2015). Pengembangan Tes Diagnostik sebagai Alat Evaluasi Kesulitan Belajar Fisika. Volume 6 Nomor 12015 ISSN: 2302-7827.

Sudijono, Anas. (2011). Pengantar Evaluasi Pendidikan. Jakarta : Rajawali Pers.

Sugiyono. (2015). Metode Penelitian Pendidikan. Bandung: Alfabeta.

Suwarto. (2013). Pengembangan Tes Diagnostik dalam Pembelajaran. Yogyakarta : Pustaka Pelajar.

Tatlah, ljaz Ahmed, dkk. (2017) . An Investigation of Students' Learning Difficulties in Mathematics at Secondary Level. India: Colloge Road Towship Lahore.

Waskito \& Kumaidi. (2010). Asesmen untuk memantau kualitas pendidikan. Pengem-bangan model analisis prestasi belajar untuk mengidentifikasi kesulitan belajar peserta didik. Jakarta: UIN Syarif Hidayatullah Jakarta.

Zaleha. (2017). Pengembangan Instumen Tes Diagnostik VCCI Bentuk Four-tier Test pada Konsep Getaran. Bandung: Universitas Pendidikan Indonesia, Bandung. 